\title{
Comparison of nomenclature and classification systems of sport injuries in elected countries with Iran
}

\author{
Safdari R ${ }^{1}$ (Ph.d.)-Reisalsadat A(M.D.)-Kordi R (M.D.)-Majidi B*(Msc.) \\ 1Associate professor, School of Allied Health Sciences, Tehran university of Medical Sciences, Tehran, \\ Iran \\ 2Assistant professor, School of medicine, Shahidbeheshti University of medical sciences, Tehran, Iran \\ 3Associate professor, School of medicine, Tehran university of medical sciences, Tehran, Iran \\ 4Master of sciences in Medical Records, school of Allied health sciences, Tehran University of medical \\ Sciences, Tehran, Iran
}

Abstract

Background : Today, sport injuries form considerable part of social events. Prevention and management of sport injuries necessitate the existence of a comprehensive system for recording and classification of data. The object of this research was study of specialized sport injuries classification system for modeling of national sport injury classification system.

Methods: This descriptive-comparative study conducted in 2012 .The sport injuries classification systems in USA ,Canada, Australia and Iran were studied .Method for data gathering was checklist that completed with valid library and internet sources.Then, data analysis performed with comparative tables.

Results: Results showed that developed countries were acted to existence of national sport injuries classification system. It adapted with international classification system of diseases and international classification of external causes of injuries .Iran lacks national sport injuries classification system.

Conclusion: Designing and using of sport injuries national classification system will have important role in prevention and releasing of sport injuries in Iran. Designing of national sport injuries classification system using of developed countries experiences recommends.

Key words: coding system, sport injuries, nomenclature and classification

*corresponding Author: Majidi B;

Email:bentalhoda.majidi@yahoo.com

\section{Introduction}

Sport injuries have happened to wrong physical activities or with more usual activities and it causes limitation sport activities in one or more days. Sport injuries have happened with acute or chronic. These injuries imposes more economic costs to each society .So, need to sports injury data management to prevent and reduce is mandatory for us. Nomenclature and classification system play the main role in sports injury data management. Without use standardized systems , there is no mean to determine and classiffing patient information process. Then,every year many standardized the system of nomenclature and classifying and submit patient information for comparison objective has established(1).coded data use foranalysis Epidemiological and management objectives (2). The goal of this research is study of 
sport injury classification system in selected countries and suggest a national classification system in Iran .

\section{Method}

This research has used Description - Comparison method in 2012 .Statistical sampling for this research was a sport injury classification systemin the USA, Canada,Austria and Iran .I used the checklist for collecting data .These data, gather form validated information on the internet then I analyzed them in comparison tables .

\section{Finding}

In the USA country, The standard Nomenclature system was established by USA medical society in 1964 .This book offers a clear definition of the standard terms so that provides naming degree and type of sportinjuries, for example sprain with three degrees : Mild, Moderate and Acute has been in the book (1).

National urgent injury events classification system was established by the Consumer Product Safety Commission (2) In the USA for classification tools to create events as well as sports. The NEISS's codes used international classification external causes(3).For example, when a person has injured from Basketball sport, four digit code was extracted from the book. A brief version of the ICECI has prepared by the center for Diseases Control and Prevention (CDC)is included goals, injury mechanism , tools, types of activities and place of events (4).

Canada country in 1999 designed a Sport-Medicine Diagnostic Coding System by central of Sport-Medicine of Calgary university in Canada. This system is so flexible and has more than 1000 codes. It has the ability to expand. Each code consists six characters, two letters and four digits(5).

The first part of SMDCS includes two letters that indicate the place of injuries, for example HE means Head and NE means Neck.Also next two digit use of structure for example 1 use for muscle , 2 for Nerv , 3 for Bone and etc.And the last digit use for injuries that indicate recognize the code. For example , 01 uses for Sprain, 07 for strain , 08 for muscle cramps, 09 for rupture, 10 for dislocation, 13 for acute fractures and so on. You can see International Classification of Diseases cross of the code (6).

In Australia country for coding type of injuries use ICD10AM and The Orchard Sports InjuryClassification(7).Many countries use recognized classification system Orchard for the coding type of sport injuries .First time Mr, Dr John Orchard designed it in Sydney university in 1992. This system is in internet with free charge and has more than 200 codes (8).

OSICS is available in paper ad paperless format.The paper format includes seven pages (first pages indicate anatomy and other pages indicates functional group ). The paperless format so like ICD10AM and emphasis to key keyboard that has typed and selected a code (8).For classification type of sport activities used ICECI codes $(9,10)$. 
The orchard 9th edition has three digit codes and Orchard $10^{\text {th }}$ has four digit codes . The first version of it was established for football and then has used for Tennis, Rugby , Cricket and so on .In $1998,6^{\text {th }}$ edition , $20007^{\text {th }}$ edition and $20028^{\text {th }}$ edition were established .Three digit version has not covered needs then in 2007 was created four digits (11).

The code of the last version of Orchard is four letters and the first letter indicate the place of anatomy injury . For example $\mathrm{H}$ means Head and $\mathrm{N}$ means Neck and so on .The second letter indicates the type of injury and also show defined list of characters.For example Laceration/Abrasion defined by $\mathrm{H}$ letter .Third and fourth letter uses for describing more about injury (11)

In Iran country, there was not established national sport injury classification system.

Table 1: Comparison specialist nomenclature and classification sports injuries systems in selected countries

\begin{tabular}{|c|c|c|c|c|c|c|}
\hline Country & System name & Organization & Count & $\begin{array}{l}\text { System } \\
\text { Type }\end{array}$ & $\begin{array}{l}\text { Code } \\
\text { structure }\end{array}$ & $\begin{array}{l}\text { Match } \\
\text { specificity }\end{array}$ \\
\hline USA & $\begin{array}{l}\text { SNAI } \\
\text { NEISS } \\
\text { Short version } \\
\text { of ICECI }\end{array}$ & $\begin{array}{ll} & \text { AMA } \\
& \text { CPSC } \\
\text { CDC } & \end{array}$ & $\begin{array}{l}\text { Single-axis } \\
\text { Multi-axis }\end{array}$ & $\begin{array}{l}\text { Diagnostic } \\
\text { Factor } \\
\text { Factor }\end{array}$ & $\begin{array}{l}- \\
4 \text { characters } \\
3-8 \\
\text { characters }\end{array}$ & $\begin{array}{l}\text { ICECI } \\
\text { ICECI }\end{array}$ \\
\hline Canada & SMDCS & Calgary university & Single-axis & Diagnostic & 6 characters & ICD \\
\hline Australia & $\begin{array}{r}\text { ICD10 } \\
\text { AM(U50- } \\
\text { U72) }\end{array}$ & $\begin{array}{l}\text { Australian Health } \\
\text { and welfare } \\
\text { Institute } \\
\text { John Orchard }\end{array}$ & $\begin{array}{l}\text { Two-axis } \\
\text { Single-axis }\end{array}$ & $\begin{array}{l}\text { Factor } \\
\text { Diagnostic }\end{array}$ & $\begin{array}{l}5 \text { characters } \\
4 \text { characters }\end{array}$ & $\begin{array}{l}\text { ICECI } \\
\text { ICD }\end{array}$ \\
\hline
\end{tabular}

\section{Discussion :}

According to classification system ICD is the reference for diseases and hygiene situation and use it was very boring then developed countries regarding with two international classification systems by world health organization( WHO) , ICD and $\mathrm{ICECl}$, start to design and develop special national sport injury system $(12,13)$.According by John Orchard and his collages study in 2004 in sport medicine clinics, they found that the Orchard classification system more faster ICD10AM in the coding process $(14,15)$. Also according Hammond this collage study in 2009 on OICS claasification system, they pointed to that last version of OSICS is so user findly and for this reason country use it (16).

Also in Iran, this study has been done .In the PhD thesis by Dr Safari in 2001 was emphasized to create a national disease classification system, and customize with 
national formatting .In Mr Ghorbani and Givi 's thesis, regarding by their study, they pointed to the effective role of the national classification system .Mrs Afifiyan developed national Oral diseases system in 2011.according by our study, to save time on coding and create a user friendly system, we need to establish and develop special sport injury classification system regarding by other countries'experiences .

\section{Conclusion}

Sport injuries in order to classification needed for recognition or patient with environmental conditions and a root cause of them. As regarding that the world health organization designed ICECI system for classification root and condition of injury and sport injuries are unintentional injuries and need to use system for 4-axis, type of activities, Place event, tools and injury mechanisim.Create National classification sport injuries match with the international classification patient system and classify

\section{Suggestions:}

Create National sport injuries classification match with ICD and ICECI that use 4-Axies to classify sport injuries is mandatory .In this regard, the customize classification system with the country's need is mandatory

\section{References:}

1. Safdari R.Nomenclature and classification systems of diseases and modeling for national classification system of disease. Tehran:mirmah; 2003.p21,36[Book in Persian].

2.Safdari R, Partovipour E, Maidani Z.Unified medical language the infrastructures of EHR.Tehran:Jaffari;2008.p48[Book in Persian].

3.U.S Consumer Product Safety Commission .NEISS Product Code.USA ;2011.available from:http://www.cpsc.gov/NEISS/completemanual.pdf

4.Lee.Annest J,Pogostin Ch.CDC's Short Version of the ICECI,International Classification of External Causes of Injury APilot Test .USA:Center for Diseaes Control and Prevention;2000 sep.

5.Meeuwisse WH, Wiley JP. The Sport Medicine Diagnostic Coding System. Clin J Sport Med.2007 May;17(3):205-7.

6.university of Calgary.Sport Mmedicine Diagnostic Coding System.Canada;1999.available from:http://www.sportmed.ucalgary.ca/sport_medicine

7.Finch C,Harrison J,Harvey D,Burns R,Williams J.Australian Sport Injury Data Dictionary.Australia:Australian Institue of Health and Welfare;1997.available from:http://sma.org.au/resources/dictionary.

8.Til L,Rae K,Orchard J.The Orchard sports injury classification system(OSICS)Version 10.Clin J Sport Med2007 May,17(3):201-4. 
9.Hoi-Yen Soo I,Klam M,Rust J,Madden R.Do we have enough information?How ICD10-AM Activity codes measure up?health informatopn management,2009;38(1):22-34.

10.Mitchell R,Boufous S, Finch C. Trends in sport/leisure injury hospitalisations (20032005) and the prevalence of non-hospitalised injuries (2005).University of New South Wales:NSW Injury Risk Management Research Centre;2008 July.

11.Orchard J,Rae K,Brooks J, Hagglund M, Til L, Wales D,et al. Revision, uptake and coding issues related to the open access Orchard Sports Injury Classification System(OSICS)version 8,9and 10.1.Open Acces Journal of Sports Medicine 2010 oct1: 207-214.

12.kozlowskia K, Leddy J, Tomita M, Bergen A,willer B.Use of the ICECI and ICD-10 E- coding structures to evaluate causes of head injury and concussion from sport and recreation participation in a school population. NeuroRehabilitation 2007;22(3):191198.

13. Overpeck M, Pickett W, King M, Garner M, Marshall L, Trifiletti L,et al. Application of the ICECI Classification of eExternal Cause of Injury to the WHO Health Behavior in School-Aged Children Survey. National Institute of Child Health and Human Development 1997.

14.Rae K, Britt H, Orchard J, Finch C. Classifying Sport Medicine Diagnoses: A Comparison of the International Classification of Diseases 10 Australian modification (ICD 10 AM)and the Orchard Sport Injury Classification System(OSICS- 8).BJSM 2005Dec;39(12):907-11.

15.Finch C,Orchard J,Twomey D, Saleem M, Ekegren C,Lioyd D,et al. Coding OSICS sports injury diagnoses in epidemiological studies: Does the background of the coder matter?, Br J Sports Med 2012 Aug.

16.Hammond Le,Lilley J,Ribbans WJ.Coding Sports Injury Surveillance Data;has version 10 of the orchard sports Injury Classification System Improved the classification of sports medicine diagnosis?,Br J Sports Me,2009 Jul;43(7):498-502.

17.Safdari R, Maleki M, Ghorbani V.Comparison of Cardiovascular Diseases Classification in Some developed countries with iran.payavard salamat;2009:3(1,2)5056[Article in Persian]. 